DOI: https://doi.org/10.34069/AI/2021.44.08.6

How to Cite:

Slinko, S.V., Yepryntsev, P.S., Shapar, A.O., Sanakoiev, D.B., \& Harkusha, A.H. (2021). Modern indicators of financial crimes detection and their prevention in Ukraine. Amazonia Investiga, 10(44), 61-72. https://doi.org/10.34069/AI/2021.44.08.6

\title{
Modern indicators of financial crimes detection and their prevention in Ukraine
}

\section{СУЧАСНІ ІНДИКАТОРИ ВИЯВЛЕННЯ ФІНАНСОВИХ ЗЛОЧИНІВ ТА ПРОТИДІЯ ЇМ В УКРАЇНI}

Received: July 10, 2021
Accepted: August 30, 2021

Written by:

Sergey V. Slinko ${ }^{24}$

https://orcid.org/0000-0001-8611-3759

Pylyp S. Yepryntsev ${ }^{25}$

https://orcid.org/0000-0002-9790-9565

Artem O. Shapar ${ }^{26}$

https://orcid.org/0000-0001-5327-701X

Dmytro B. Sanakoiev ${ }^{27}$

https://orcid.org/0000-0002-6783-3168

Alina H. Harkusha ${ }^{28}$

https://orcid.org/0000-0002-3299-8405

\begin{abstract}
The increase in the level of financial crime is caused by the technological development, weak moni-toring of financial institutions, low level of international cooperation in terms of combating these types of crimes. The paper aims to develop effective ways to combat financial crimes in Ukraine. With the help of a systematic analysis of financial crime modern indicators, theoretical sources, prac-tical measures and international experience, the main indicators of financial crimes are identified. Such indicators are the use of false documents and other people's accounts, international payment systems; frequent and complex financial transactions of a confusing nature; unusual for a client amounts and counterparties of the transaction; incomplete or missing payment information. The study has found that the increase in the level of financial crime is influenced by the presence of off-shore zones, the low level of liability for the crime, the reluctance of financial institutions to interact with law enforcement agencies in regard to combating such crimes. It is possible to increase
\end{abstract}

\begin{abstract}
Аннотація
Підвищення рівня фінансової злочинності зумовлено технологічним розвитком, слабкістю моніторингу фінансових установ, низьким рівнем міжнародної взаємодії в аспекті протидії таким видам злочинів. Тhe paper aims to вивити ефективні способи протидії фінансовим злочинам в Україні. За допомогою системного аналізу сучасних індикаторів фінансової злочинності, теоретичних джерел, практичних заходів та міжнародного досвіду визначені основні індикатори фінансових злочинів. Такими індикаторами $\epsilon$ використання несправжніх документів та чужих рахунків, міжнародних платіжних систем; часті та складні фінансові операції заплутаного характеру; незвичні для клієнта суми та контрагенти операції; неповна або відсутня інформація про платіж. В результаті дослідження визначено, що на підвищення рівня фінансової злочинності впливає наявність офшорних зон, низький рівень встановлення відповідальності за скоєний злочин, небажання фінансових
\end{abstract}

\footnotetext{
${ }^{24}$ Doctor of Law, Professor, Kharkiv National University of Internal Affairs, Ukraine.

${ }^{25}$ Candidate of Law, Director of the Kryvyi Rih Educational and Scientific Institute of the Ministry of Internal Affairs of Ukraine, Kryvyi Rih, Ukraine.

${ }^{26} \mathrm{PhD}$ of Law, Associate Professor Deputy Director for Educational and Research Activities of the Kryvyi Rih Educational and Scientific Institute Donetsk State University of Internal Affairs, Kryv-yi Rih, Ukraine.

${ }^{27}$ Associate Professor, Candidate of Juridical Sciences, Dnipropetrovsk State University of Internal Affairs, Dnipro city, Ukraine.

${ }^{28}$ Associate Professor, Candidate of Juridical Sciences, Associate Professor of the Department of Criminal Procedure, Dnipropetrovsk State University of Internal Affairs, Dnipro city, Ukraine.
} 
the level of financial crime counteraction by conducting an external audit and investigation of financial crimes, establishing international cooperation to combat such crimes, blocking suspicious financial transactions, taking preventive measures and combating related crimes.

Key words: audit, crime, fraud, international organizations, Ukraine. установ взаємодіяти із правоохоронними органами в аспекті протидії таким злочинам. Підвищити рівень протидії фінансовій злочинності можливо за допомогою проведення зовнішнього аудиту та зовнішнього розслідування фінансових злочинів, налагодженню міжнародної взаємодії щодо протидії таких злочинам, блокування підозрілих фінансових операцій, проведення профілактичних заходів та боротьба 3 пов'язаними злочинами (корупцією, кіберзлочинністю, відмиванням грошей). В результаті підвищення ефективності протидії фінансовій злочинності в Україні підвищиться рівень економічної та політичної стабільності.

Ключові слова: аудит, злочинність, шахрайство, міжнародні організації, Україна.

Achim et al. (2021) analyze the increase of financial crime rate: referring to the level of corruption, Lagarde (2016) confirms that 2 percent of world gross domestic product is paid in the form of bribes annually, amounting to 1.52 trillion USD per year worldwide. In addition, Achim et al. (2018) find that 19 percent of European countries' GDP is lost in the shad-ow economy. The results of economic crimes and fraud study show that $17 \%$ of organizations in Ukraine suffer from fraud related to unethical professional behavior of employees (PwC, 2018).

In order to combat financial crimes effectively, it makes sense to analyze common tools for committing such crimes, modern indicators and criteria for detecting such crimes, international expe-rience in combating financial crimes, which can help identify effective ways to minimize and com-bat financial crime.

The paper aims to identify effective ways to combat financial crime in Ukraine based on the analysis of financial crime modern indicators, theoretical sources, practical measures and interna-tional experience in detecting and combating financial crime.

\section{Metodology}

Financial crime is an interdisciplinary study object, so it is advisable to study a comprehensive approach including general theoretical and special cognition methods. The methodological basis of the study involves such 


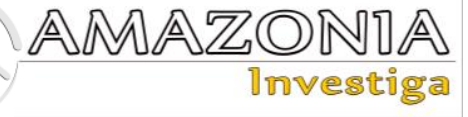

general scientific methods as the dialectical method of scientific knowledge, which determines the development of financial crime, as well as the relationship between financial crime and other crimes (corruption, cybercrime) affecting the security of the state as a whole. Due to the application of classification method and systematic analysis, the main forms, features, methods and tools of financial crimes are identified. The grouping method and the systemstructural approach allowed to classify modern financial crimes and to define the main groups of persons who commit financial crimes.

Based on the systematization of theoretical data and practical measures used by leading countries, the most effective indicators for detecting financial crimes have been identified. Indicators and measures to combat financial crime in other countries were analyzed. The generalization of indicators for the detection of financial crimes in other countries (USA, France, Italy) allowed to determine the system of indicators for the detection of such crimes in UkraineBased on the method of comparative law, effective measures to combat and prevent financial crimes in Ukraine have been identified. The logical and legal method allowed to identify the main preventive measures, which can reduce the level of financial crime in Ukraine, to identify the main indicators increasing the level of crime detection in the financial sector. Due to the method of generalization, universal measures to combat financial crime are identified; conclusions and research proposals are formulated.

\section{Literature review}

The scientific research is based on the works of modern domestic and foreign scientists, the subject of research of which is financial crime, its peculiarities and methods of counteraction. Gottschalk (2010) classified a wide range of financial crimes and distinguished four main categories: corruption, fraud, theft, and manipulation. O. Bura and I. Dobrovolska (2017) distinguish the financial pyramid, job search fraud, "marriage" fraud, carding, phishing among the types of financial crimes.

Identifying the roots of financial crimes can identify effective prevention and monitoring measures to minimize financial crime and ensure quality financial reporting (Razaee, 2005). Likewise, another documentary type investigation could infer that the forensic audit is that work that focuses on the prevention and detection of financial fraud. For this reason, the results of the Forensic Auditor's work are generally brought before the courts (Arbeláez C., et al, 2013).

Financial crimes are related to cybercrime, as criminals enjoy the benefits of ICT. McGuire and Dowling (2013) state that fraud and theft are the most common cases of cyber technology application to commit a crime.

Snyder and Khreshchentsi (2009) note that the intellectual property of criminals is related to cybercrime, and that the increase in cybercrime level gives the way for the victimization of the intellectual properties of business.

Weakness and low authority of state power, low efficiency of law enforcement mechanisms can be a source of increasing the shadow economy and financial crime (Paientko, 2013).

"Fraud", "corporate crime" and "white-collar crime" are the terms that can be used in reference to financial crimes. Financial crimes are illegal acts committed by both an individual and a group of individuals to achieve financial or professional benefits (O'Brien, 2019) The increased public danger of criminal activity in the financial sphere may lie in the fact that the state as a whole (represented by public financial institutions, public companies and institutions, pension funds, etc.), private companies and individual investors suffer losses (Tikhonova, 2018).

L. Kryvoruchko and P. Nazarenko (2012) identify the following ways (types) of committing financial crimes:

- crimes in the banking sector using: criminal schemes of banks bankruptcy; "Electronic fraud"; making duplicate keys of bank customers' repositories; disclosure of insider information; currency transactions;

- crimes in the field of credit relations with the use of: unjustified closure of pledge on the basis of falsified fax messages and photocopies of documents; express credit granting in stores, etc.;

- crimes in the field of securities circulation with the use of: a fictitious agreement of sale and purchase; forged documents and securities; fictitious securities; specially created computer programs or the Internet to penetrate the database of registration and depository companies and change information about the owners of securities for the own benefit; creation of a "financial pyramid" with the use of securities; 
- crimes committed by creating financial pyramids using network marketing and the main forms of attracting trusting customers.

Western Union provides information on its official website about the following types of crimes: advance payment fraud, employment fraud, lotteries fraud, property lease fraud, fraud involving emergency situation with relatives, online shopping fraud, Internet dating fraud, fraud involving forgery of payment receipts (Western union, 2021).

One of the common types of financial crime is falsification of financial statements. This is confirmed by a study of the international company PricewaterhouseCoopers, which among the most "popular" economic crimes and frauds in 2018 (along with bribery and corruption, misappropriation of property, fraud in the field of procurement and taxation) also distinguished falsification of financial statements (Ukraine - $13 \%$ and global index - 20\%) (PricewaterhouseCoopers Ukraine, 2011).

The Association of Certified Fraud Examiners (ACFE) in its research conducted in 2018 "Report to the Nations" distinguishes the most common fraud schemes, which include: misappropriation of assets, corruption and falsification of financial statements.

D.M. Kharko (2010) identifies the following features of economic crime:

- $\quad$ it is a type of crime that is used mainly en masse, respectively, causes mass damage;

- it covers various economic power abuses;

- it is committed in the process of professional activity of the manager's power;

- it has a plurality of crime episodes;

- $\quad$ it is committed by both individuals and legal entities;

- it is a more complex socio-economic phenomenon than traditional crime;

- it has a latent character;

- it causes significant economic damage to the state interests.

The Internet can be considered an environment for the spread of financial crime (Wall, 2007). Michel (2008) states that financial crime is caused by opportunities for criminals and weak liability imposing procedures. This statement is mainly based on the theory of rational choice. If criminals think they can benefit more from financial crimes compared to the costs spent and probabilities to be punished, it is worth the risk. This allegation is related to the justification of money laundering and tax evasion. If criminal proceeds are guaranteed, it will increase the level of financial crimes. If the state succeeds in creating conditions where the cost of complying with the law (law-abiding behavior) is significantly lower than the cost of illegality or evasion of punishment, this may be the best step towards overall crime prevention. The fact is that when the price of lawful behavior is higher than the price of illegal behavior, a person makes a decision in favor of the latter activity option. This testifies the fact that the person, after analyzing the losses and benefits of his or her actions, draws a conclusion that directly affects the decision. A person weighs all the pros and cons and chooses the behavior that will provide him or her the greatest personal benefit with the least loss, in particular with the least risk of punishment (Melnichuk, 2009).

O. Tykhonova (2019) draws attention to the importance of taking preventive measures when combating against financial crimes.

However, relying on prevention alone cannot completely combat financial crime, as such crimes are very creative and can take any form. Each new financial crime case includes a unique component that leads to the failure of existing prevention methods. Therefore, due attention should also be paid to detection methods (Bolton \& Hand, 2002).

A. Kovbel (2019) notes that business owners in Ukraine underestimate external forms of control (external audit, involvement of external consultants to conduct independent investigations); Only $10 \%$ of Ukrainian organizations have experience in engaging external consultants for independent investigations" (Kovbel, 2017).

Sadgali et al (2019) note that various methods of money laundering (especially artificial intelligence methods) can be applied to detect credit card crimes. The best methods for detecting crimes in financial reporting are probabilistic neural network and genetic algorithm (Sadgali et al., 2019). The use of such technologies allows data to be systematized, risks to be profiled, and the origin of illicit funds used for criminal purposes in the future to be detected (Levi \& Wall, 2004; Amoore \& de Goede, 2005).

Against the background of significant amounts of illegal financial flows, the frauds involving the funds theft from customer accounts, minor manipulations in the securities market and in the non-bank financial institutions sector cannot be 


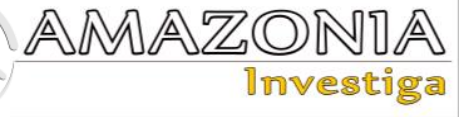

ignored. The motives for such manipulations are not only related to profit, but also to the low probability of punishment. Despite the relatively small volumes (in isolated cases), in the aggregate such criminal actions can cause significant financial and reputational damage to the economy of Ukraine (Chunytska, 2017).

The Financial Privacy of such countries as Switzerland and the Cayman Islands provides favourable conditions and environment for financial crime, market manipulation and money laundering (Ruggiero, 2015).

Some financial crimes occur on their own, and some may involve other types of crimes financial and non-financial. Financial crimes include money laundering, cyber- and technological crime, personal crime, exploitation of business structures and corruption in the public sector. Such criminal activity exists in itself and becomes the basis for other types of organized crime. All this can complicate the process of detecting and investigating financial crimes and bringing criminals to justice. When a financial crime is committed by an employee of a financial institution, it is difficult for law enforcement officers to bring him or her to justice for illegal transactions. Law enforcement officers can impose multimillion-dollar fines on large financial institutions and banks instead of bringing charges against individuals (Jeyong, Julak, 2017).

Each country has a specific body, which conducts financial investigations and has a number of powers vested in a special body (Grudzevych, 2009, p. 169). Rider et al (2014) also draw attention to the importance of interaction between government authorities and law enforcement agencies in the fight against financial crime. Because during the economic crisis, the financial system of each country is exposed to a number of factors creating the conditions for illegal encroachments on the financial interests of the state. It is important that special services cooperate with law enforcement agencies of foreign countries, as crimes in the financial sector become international (Pik, 2013). Zoldi (2015) notes that an integrated analytical approach, which will be constantly improved and updated, is essential in combating financial crimes. D.S. Rohovenko (2011) notes that in combating financial crimes it may be appropriate to create a single information base regarding fraud cases in the financial market of Ukraine. "The exchange of information on suspicious cases and joint investigations are quite effective means of combating encroachments on financial institutions" (Rohovenko, 2011, p.59).

Ryder (2011) notes that the integrity of the financial system can be destroyed through financial crimes, and the consequences of financial crime can be a threat to national security.

Vitvitskiy et al (2021b) note that rapid and timely exchange of information can increase the process of crimes investigation in the financial system. Rahman \& Anwar (2014) note that it is not advisable to rely on the technical means of crimes detection when combating against financial crimes, as financial crimes are constantly being modernized.

It makes sense for the countries to cooperate in terms of legal assistance, extradition and the exchange of intelligence information to reduce crime. It is important to develop an international integrated legal system to combat crime so that such criminal investigations can be carried out regardless of national borders. (Tishchenkova et al, 2019).

It is also important to combining the efforts of various social institutions in the direction of raising the level of welfare of the nation, educational and training work with vulnerable strata of the population (young people, former prisoners, participants in hostilities, etc.), and support of moral principles in society, humanity, which can reduce crime in the country (Tishchenkova et al, 2018).

\section{Results and discussion}

Financial crimes can be the main threat to the country's financial systems, as the level of their commission is constantly increasing, and at the same time, the data on financial crime may not always reflect its actual level, which confirms the study by Antinori (2018).

The impact of fraud and economic crime on all organizations around the world is still significant. The most common scheme of financial crimes is misappropriation of assets, when an employee steals or misuses the resources of the organization (ACFE Report To the Nations, 2020). The process of preventing financial crimes can be expensive and time consuming, but combating against financial crime ensures the optimal development of society. Effective corporate governance can play an important role in the financial crime management (Murphy and Free, 2016). 
Modern financial crimes in the modern world can take the following forms:

- life insurance fraud;

- property insurance fraud;

- theft;

- illegal withdrawal of loans;

- money laundering;

- personal information theft;

- extortion from the senior citizens (Business Forensics, 2021)

There are seven groups of people who commit various types of financial crimes:

- Organized criminals, including terrorist groups, who commit large-scale fraud to finance their operations.

- corrupted heads of state who can use their position and powers for their own enrichment.

- business leaders or senior executives who manipulate or misrepresent financial data in order to conceal the true financial position of the company.

- employees stealing company funds and other assets.

- customers, suppliers, contractors or persons who are not related to the organization.

- conspiracy of external criminals with an employee to achieve a better and simpler result.

- personal criminal fraudsters, serial or opportunistic individuals who own their income (ICA, 2021).

The main forms of financial crime in cyberspace are electronic financial, fraudulent sales via the Internet or retail sites, mass marketing fraud, phishing and online dating sites.

Based on the analysis of legal documents and reports of the State Financial Monitoring Service, the instruments of financial crime in cyberspace are identified:

- use of accounts set up for lost or forged documents;

- opening an account in the name of lowincome citizens and enterprises with signs of fictitiousness;

- use of international payment systems;

- conducting chain financial flows through several bank accounts using remote access;

- electronic funds and cryptocurrencies;

- involvement of fictitious persons.
Terrorist financing is one of the types of financial crime. The most common tools in such schemes are as follows:

- providing financial assistance;

- agreements on assignment of claims;

- use of charitable organizations;

- involvement of fictitious persons.

Criteria for identifying financial transactions for terrorist financing may be as follows:

- receipt of funds in small amounts from different persons for a short period of time in favor of one person with the payment purpose description "help", "for treatment", "charitable help", "kindness";

- the recipient and / or initiator of the funds transfer is a public and / or charitable organization;

- unusual for the client amount of financial transaction;

- $\quad$ unusual counterparty for the client;

- uncharacteristic payment purpose description of the client's financial transaction;

- payments made by persons who do not fully know or reluctantly report the details of the payment;

- electronic transfer payment transaction, in which there is no complete information about the initiator or recipient;

- confusing nature of the financial transaction;

- lack of economic content (State Financial Monitoring Service of Ukraine, 2017).

The formation and development of the informal economy and the growth of illegal financial flows are fueled by the successful operation of offshore zones. The stable demand for doing business in offshore zones may be conditioned by the institutional factors (institutional deformations of the Ukrainian economy, lower transaction costs). Low transaction costs are related not only with a lower level of tax burden, but also with the exemption from taxation of passive income, the ability to keep accounts in foreign currency, no reporting in some countries (eg, Belize, Panama, British Virgin Islands), free registration, low operating costs, etc., which confirms the study by Paientko (2013).

In the study, it is advisable to analyze countering financial crime in developed countries. Among the bodies, which investigate financial crimes in the United States, a special place is occupied by the Financial Crimes Enforcement Network (FinCEN). Its competence includes the 


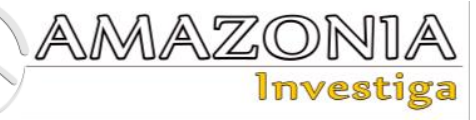

collection, processing, analysis and classification of financial information with its subsequent transfer to the competent authorities. To effectively analyze financial information, FinCEN has extensive sources of information, including access to the National Security Agency information. An important aspect of FinCEN's work is its interaction with other organizations in order to cooperate during the investigation of financial crimes. In particular, FinCEN has entered into an agreement with the Committee for the Processing of Intelligence Information and the Fight against Illegal Networks of Financial Institutions (Tracfin), which operates under the French Ministry of Finance. FinCEN also signed an agreement with the UK's National Criminal Intelligence Network (NCIN) (Lepsky, 2014).

According to the Federal Bureau of Investigation, in the United States, financial crime is mostly manifested in the form of corporate fraud, mortgage fraud, investment fraud. One of the distinctive display of financial crime in the United States is corporate fraud, which involves the manipulation of financial data and insider information trading. In 2016-2018, about 2,300 of such facts were revealed, the losses for which amounted to more than 3.7 billion dollars. (FBI, 2018).

According to the FBI data, the number of cases involving falsification of financial information remains relatively stable, while there is a sharp increase in the number of cases of insider information trading (Klochko, 2013).

In France, the financial intelligence unit operates within the Ministry of Economy, Finance and Industry and is divided into three units for efficient data processing, in particular: Information Collection Center, State Expertise Department, Operational Department. In the Federal Republic of Germany, the financial intelligence units are part of the police and have the following powers: collection and analysis of reports on suspicious financial transactions; transfer of analysis results to law enforcement agencies; providing financial monitoring institutions with information on money laundering methods (Kuchmii, 2020).

In Italy, a specialized body has been created to investigate financial crimes, the Financial Guard, which is subordinated directly to the Ministry of Economy and Finance. The main tasks of the Financial Guard are as follows:

- tax control;
- implementation of customs control;

- control over the spending of public funds;

- $\quad$ supervision of excise taxes;

- supervision of legality during public procurement;

- combating organized crime;

- counteraction to counterfeiting of coins and banknotes;

- prevention and combating fraud in the EU system;

- protection of patents, copyrights, including national products and Italian trademarks;

- organization of interaction with other law enforcement agencies, controlling bodies of the country. Financial investigations are carried out by the Financial Guard both under the supervision of the prosecutor and independently (Marchenko, 2017).

The international organization FATF (2019) is important in the field of combating financial crimes. The FATF Recommendations establish a comprehensive and coherent framework for measures that countries should apply to counter money laundering and terrorist financing and the financing of the proliferation of weapons of mass destruction.

Thus, the ways to increase the effectiveness of preventive activities in ensuring the financial security of the state are:

- increasing the requirements for persons who receive appeals from citizens about the facts of violations in the financial system of the state;

- determination of criteria for evaluating the work of law enforcement agencies on crime prevention;

- intensification of public participation in compliance with the legislation governing financial activities in the state;

- ensuring the development of international cooperation in the field of financial offenses prevention;

- creation of a single database in which information on illegal activities of persons will be accumulated;

- introduction of active educational activities aimed at forming a negative attitude to illegal acts committed in the financial system;

- fiscal policy improvement, introduction of an effective control system over the sale of goods in the domestic market;

- prevention of illegal goods transfer across the customs border; 
- improving information support for crime prevention and citizens' protection from illegal encroachments on their rights in the field of formation and circulation of finances through mass media.

Based on the analysis of literature sources, the most common tools for corporate financial crimes detecting are identified:

- Compliance is a set of statutory provisions, internal policies and company regulations, which must be followed by each employee. Compliance covers corporate ethics policies, reporting breaches, maintaining data confidentiality, resolving conflicts of interest, etc. (Khamyha, 2020);
- annual audit of financial statements;

- whistle blowing system (WBS) - a feedback system which allows to identify fraudulent actions by third parties with the help of people working for the company (Kovbel, 2019).

Conducting a financial audit may be ineffective in case when financial institutions conceal existing shortcomings in order to maintain their customer base and trust level (Vitvitskiy et al, 2021a).

Analysis of the main features, forms and methods of committing financial crimes allows to determine the main indicators by which the following types of crimes can be detected.

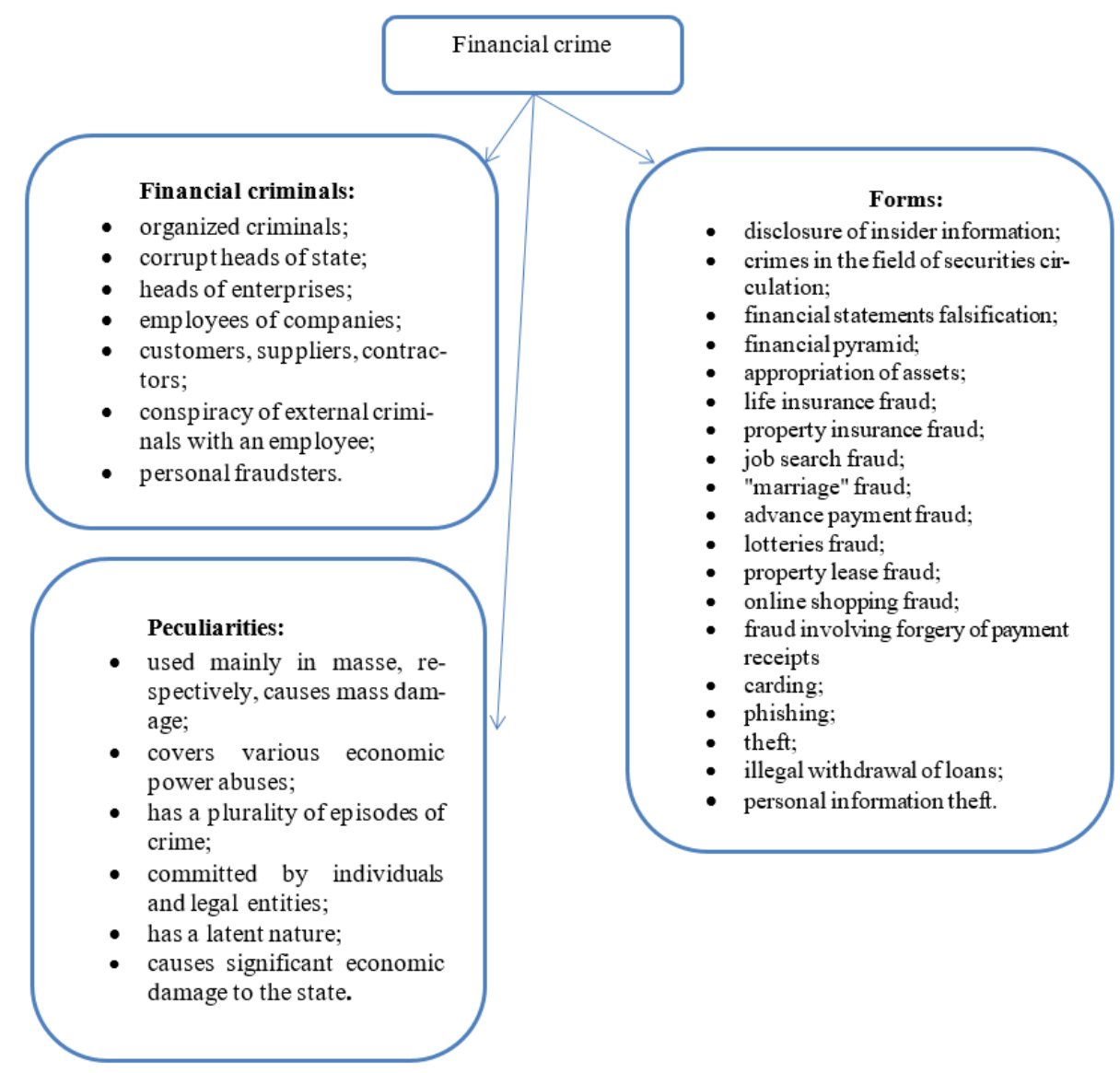

Figure 1. Financial crime in Ukraine (developed by the authors)

The main indicators of financial crime are as follows:

- use of false documents for financial transactions;

- use of international payment systems;

- use of someone else's accounts to commit a crime;
- conducting frequent small scale financial transactions;

- unusual for the client amount of financial transaction;

- $\quad$ unusual counterparty for the client ;

- uncharacteristic payment purpose description of the client's financial transaction; 
- incomplete information on the purpose of payment;

- lack of information about the recipient or initiator of payment;

- confusing nature of the financial transaction;

- lack of economic content of the financial transaction.

The increase of financial crime level may be a consequence of the low maturity of the institutional environment and the high level of information asymmetry. Financial crime can also be influenced by the merging of political power and big business, which is typical of Ukrainian society (Paientko, 2016).

Financial crime can be related to a country's economic development. Economic development affects the level of financial crime of countries in different ways, reducing the financial crime of low-income countries and stimulating financial crime of high-income countries. Unemployment, which should be reduced in developed countries to reduce financial crime, is also related to financial crime. Rising unemployment rate in low-income countries is a side effect of lowering financial crime. It is important to take into account economic development, unemployment and tax freedom rate in respect to combating financial crime. Reducing the level of tax freedom can have a positive effect on reducing the level of economic and financial crime (Achim et al., 2021).

The reduction of financial crime among employees of financial institutions can be achieved by increasing the financial motivation of employees and maintaining the appropriate level of their remuneration. Another factor reducing the level of corporate financial crime may be the moral aspect of financial institutions staff activities - fear and shame for dishonest behavior, deterioration of organization reputation. It makes sense to eradicate nontransparent accounting and reporting schemes and possible financial manipulation in the company (signing blank forms of the organization "just in case", etc.).

A combination of anti-fraud mechanisms should be applied, including financial monitoring, implementation and control of compliance with the code of conduct, increasing the level of reporting of fraud, fraud risk assessment, use of anti-fraud services, verification of information about employees and customers of financial institutions, data analysis, firewall and anti-fraud policies, and training of financial and law enforcement officials to combat fraud. Thus, the basis for combating financial crimes is the effective management of the national financial system, which is carried out by the government, the head of state and the activities of law enforcement agencies, which are tasked with combating financial crime.

Active participation of financial institutions in facilitating money laundering and terrorist financing can be an obstacle and threat to the detection of financial crimes. The reluctance of financial institutions to provide law enforcement agencies with access to information on financial crimes can be explained by the following reasons:

- fear of losing the trust of customers;

- obtaining their own benefit from financial crimes;

- desire to keep up their own reputation

- conspiracy with law enforcement, business or government officials.

Financial crimes are characterized by their interaction with other forms of crime, such as:

- corruption;

- money laundering and terrorist financing;

- cybercrime;

- operation of business structures.

The increase of financial crime rate is also influenced by the existence of offshore zones and weak procedures for establishing responsibility for committing a crime.

All this complicates the process of detecting and investigating financial crimes.

Among the universal measures to combat financial crimes, which are quite common in Western countries, we can distinguish the following ones:

1) establishing cooperation and interaction with competent authorities and international organizations to exchange information and experience in detecting and investigating financial crimes;

2) blocking suspicious financial transactions;

3) supervision over the effectiveness of state policy implementation in this area of activity;

4) carrying out preventive measures aimed at reducing financial crime;

5) combating related crimes (money laundering, terrorist financing, cybercrime, corruption); 
6) involvement of external forms of control, such as external audit, involvement of external consultants to conduct independent investigations.

As a result of identifying relevant indicators of financial crimes and increasing the effectiveness of financial crime combating, the level of crimes related to financial crimes can be reduced, which will be the basis for the stable development of the Ukrainian economy and politics.

\section{Conclusion}

Increasing levels of the shadow economy and financial crime threaten the financial security of the state. The aim of the article is to identify effective ways to combat financial crime in Ukraine. The main indicators of financial crimes are identified: the use of false documents, international payment systems, other people's accounts to commit a crime; conducting frequent and complex small scale financial transactions, unusual financial transaction for the client by amount or counterparty, unusual purpose of payment, incomplete information on the purpose of payment, recipient or initiator of payment, confusing nature of financial transaction, lack of economic content of financial transaction. Financial crimes are closely related to corruption, money laundering, cybercrime and the exploitation of businesses structures.

Criminals profit by offshore zones and a weak level of criminal responsibility. Possible ways to increase the level of effectiveness of financial crimes combating may be as follows: establishing cooperation with the relevant authorities and international organizations to share information and experience in detecting and investigating financial crimes, blocking suspicious financial transactions, improving the implementation of public policy in this area, prevention, combating against related types of crimes, involvement of external forms of control. The implementation of the above mentioned measures can have a positive impact on the economic and political stability of the state.

\section{Bibliographic references}

ACFE Report To the Nations. (2020). Global Study on Occupational Fraud and Abuse. Retrieved from https://www.acfe.com/reportto-the-nations/2020/.

Achim, M.V., Borlea, N.S., Găban, L., \& Cuceu, I.C. (2018). Rethinking the shadow economy in terms of happiness: Evidence for the European Union member states. Technological and Economic Development of Economy, 24, (1), 199-228. https://doi.org/10.3846/20294913.2016.1209 250

Achim, M.V., Borlea, S.N., \& Văidean, V.L. (2021). Does technology matter for combating economic and financial crime? A panel data study. Technological and Economic Development of Economy, 27(1), 223-261. https://doi.org/10.3846/tede.2021.13977.

Amoore, L., \& de Goede, M. (2005). Governance, risk, and data veillance in the war on terror. Crime, Law, and Social Change, 43, 149-173. https://doi.org/10.1007/s10611-005-1717-8.

Antinori, A. (2018). Systemic corruption: Weapons of the twenty-first century, organized crime and the mafia in fraud and corruption. Springer, Cham.

Arbeláez, D.F., Correa Cruz, L. and Silva, J. (2013). An approach to developments in forensic research. Tend,. 14(2), 216-230. ISSN 0124-8693.

Bolton, R.J., \& Hand, D.J. (2002). Statistical fraud detection: A review. Retrieved from http://metalab.uniten.edu.my/ abdrahim/nt1/ Statistical\%20Fraud\%20Detection \%20A\%2 OReview.pdf.

Bura, O.V., \& Dobrovolska, I.I. (2017). Financial fraud in Ukraine and countermeasures. (In Ukrainian). Retrieved from http://libfor.com/index.php?newsid=2879.

Business Forensics. (2021). The History of Financial Crime: Exploring Examples of Modern Money Crimes. Retrieved from https://businessforensics.nl/financial-crimehistory/.

Chunytska, I.I. (2017). Measures to prevent financial fraud and money laundering. Problems of Economics, 2, 282-291. (In Ukrainian). Retrieved from https://www.problecon.com/export_pdf/prob lems-of-economy-2017-2_0-pages282_291.pdf.

FATF. (2019). Guidance for a Risk-Based Approach for Legal Professionals, FATF, Paris. Retrieved from https://www.fatfgafi.org/media/fatf/documents/reports/RiskBased-Approach-Legal-Professionals.pdf.

FBI. (2018). White-Collar Crime. Retrieved from https://www.fbi.gov/investigate/whitecollar-crime.

Gottschalk, P. (2010). Categories of financial crime. Journal of Financial Crime, 17(4), 441-458.

Grudzevych, Ya.V. (2009). International experience in forming a financial intelligence body. Regional economy, 2, 166-172. (In Ukrainian). 


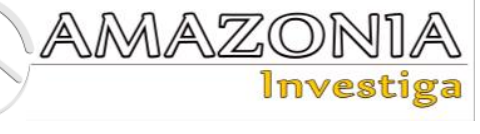

ICA (International Compliance Association). (2021). What is Financial Crime? Retrieved from https://www.intcomp.org/careers/your-career-in-financialcrime-prevention/what-is-financial-crime/.

Jeyong, J., \& Julak, L. (2017). Contemporary Financial Crime. Journal of Public Administration and Governance, 7 (2), 88-97. Retrieved from https://www.researchgate.net/publication/31 7609934_Contemporary_Financial_Crime.

Khamyha, Yu.Ya. (2020). Financial fraud: identification criteria and areas of minimization: (dissertation for the degree of Doctor of Philosophy in specialty Finance, Banking and Insurance). Western Ukrainian National University of the Ministry of Education and Science of Ukraine, Ternopil. (In Ukrainian)

Kharko D.M. (2010) Criminological problems in determining the concept and features of moderneconomic crime as a factor of shadow economy of Ukraine. Actual problems of the state and law (In Ukrainian). Retrieved from http://www.apdp.in.ua/v55/119.pdf.

Klochko, V.M. (2013). Foreign experience in criminal law protection of the securities market. Scientific Bulletin of the NAVS, 4, 275-282. (In Ukrainian). Retrieved from http://nbuv.gov.ua/UJRN/Nvknuvs_2013_4_ 39.

Kovbel, A. (2017). About fraud in Ukrainian companies. Kreston Ukraine. (In Ukrainian). Retrieved from https://krestongcg.com/en/shahrajstvo-v-ukrajinskihkompanijah/.

Kovbel, A. (2019). Fraud within the company. How to protect yourself? Interfax-Ukraine (In Ukrainian). Retrieved from https://biz.nv.ua/eng/experts/shahraystvovseredini-kompaniji-yakzahistitisya50009055.html.

Kryvoruchko, L.S., \& Nazarenko, P.G. (2012). Groups of ways to commit financial fraud as an element of forensic characterization of crimes of this type. (In Ukrainian). Retrieved from

http://eir.zntu.edu.ua/bitstream/123456789/1 363/1/Nazarenko_Groups_w ays_to_commit_financial_fraud.pdf.

Kuchmii, T.O. (2020). Features of financial investigations: the international aspect and the possibility of implementation. Accounting, Analysis and Auditing, 31 (70), 2, 159-162. (In Ukrainian). Retrieved from http://www.econ.vernadskyjournals.in.ua/jou rnals/2020/31_70_2/31_70_2_2/29.pdf.

Lagarde, C. (2016). Addressing corruptionopenly. International Monetary Fund.
Retrieved from https://www.elibrary.imf.org/view/books/07 6/23461-9781513563237-en/23461-

9781513563237-en-book.xml.

Lepsky, S.I. (2014). Foreign experience in the use of financial investigations in law enforcement. Law and society, 2, 189-194. (In Ukrainian).

Levi, M., \& Wall, D. (2004). Technologies, security, and privacy in the post $9 / 11$ European information society. Journal of Law and Society, 31(2), 194-220. https://doi.org/10.1111/j.14676478.2004.00287.x.

Marchenko, V.Yu. (2017). Financial police in Ukraine through the prism of the experience of foreign countries. Transcarpathian legal readings, 1, 202-208. (In Ukrainian). Retrieved from https://dspace.uzhnu.edu.ua/jspui/bitstream/1 ib/13716/1/\%D0\%A4\%D0\%86.pdf.

McGuire, M., \& Dowling, S. (2013). Cybercrime: A review of the evidence. Summary of key findings and implications. Home Office Research Report, 75.

Melnichuk, T.V. (2009). Organized forms of criminal activity in the foreign economic sphere. (dissertation for a scientific degree candidate of legal sciences) Odessa National Law Academy, Ukraine. 246. (In Ukrainian). Retrieved from http://dspace.onua.edu.ua/bitstream/handle/1 1300/2078/\%D0\%9C\%D0\%B5\%D0\%BB\% D1\%8C\%D0\%BD\%D0\%B8\%D1\%87\%D1 $\% 83 \%$ D0\%BA\%20\%D0\%A2.\%D0\%92..pdf ?sequence $=1 \&$ is Allowed $=\mathrm{y}$.

Michel, P. (2008). Financial crimes: the constant challenge of seeking effective prevention solutions. Journal of Financial Crime, 15(4), 383-397.

Ministry of Economy of Ukraine. (2020) Macroeconomic analysis and forecasting. (In Ukrainian). Retrieved from https://www.me.gov.ua/Tags/DocumentsBy Tag?lang=uk-UA\&id=46442994-b673481b-bdf48941551bc942\&tag=EkonomichnaSituatsiia TaMakroekonomichnePrognozuvannia.

Murphy, P.R. \& Free, C. (2016). Broadening the Fraud Triangle: Instrumental Climate and Fraud. Behaviroural research in accounting. 28(1), 41-56.

O'Brien. (2019). Battling the rising threat of white collar crime. Chartered Accountants Ireland. Retrieved from https://www.charteredaccountants.ie/News/b attling-the-rising-threat-of-white-collarcrime. 
Paientko, T., \& Fedosov, V. (2016). Bureaucracy as a public institution of government. Securities Market, 7-8, 11-22. (In Ukrainian).

Paientko, T.V. (2013). Institutionalization of fiscal regulation of financial flows. Kyiv: DKS Center, 294. (In Ukrainian).

Pik, S. (2013). Intelligence in the modern world and its priorities. Visnyk de la Universidad Nacional de Lviv. Serie: Relaciones Internacionales, 32, pp 70-76Retrieved from http://nbuv.gov.ua/UJRN/VLNU_Mv_2013_ 32_12.

PricewaterhouseCoopers Ukraine. (2011). World Survey of Economic Crime. (In Russian). Retrieved from https://www.pwc.com/ua/en/survey/2018/ec onomic-crime-survey.html.

PWC. (2018) PWC World Economic Crimes and Fraud Survey. Survey of Ukrainian Organizations. Removing fraud from the shadows. (In Ukrainian). Retrieved from https://www.pwc.com/ua/en/survey/2018/ec onomic-crime-survey.html.

Rahman, R.A., \& Anwar, I.S. (2014). Effectiveness of fraud prevention and detection techniques in Malaysian Islamic banks. Procedia-Social and Behavioral Sciences, 145, 197-202

Razaee, Z. (2005). Causes, consequences, and deterrence of financial statement fraud. Critical Perspective of Accounting, 16, 277298.

Report to the Nations. (2018). Global Study on Occupational Fraud and Abuse. Association of Certified Fraud Examiners. Retrieved from https://www.acfe.com/report-to-thenations/2018/.

Rider, N., Turksen, U., \& Hassler, S. (2014). Fighting financial crime in the global economic crisis. Routledge. Retrieved from https://www.routledge.com/FightingFinancial-Crime-in-the-Global-EconomicCrisis/Ryder-TurksenHassler/p/book/9781138218895.

Rohovenko, D.S. (2011). Ensuring anti-fraud in the field of financial services. Bulletin of the Ministry of Justice of Ukraine, 12, 55-60. (In Ukrainian). Retrieved from http://nbuv.gov.ua/UJRN/bmju_2011_12_9.

Ruggiero, V. (2015). Financial crime after the crisis in the UK. Archivos de Criminología, Criminalística Y Seguridad Privada, 5.

Ryder, N. (2011). Financial crime in the 21st century: law and policy. Gloucestershire: Edward Elgar Publishing.

Sadgali, I., Sael, N., \& Benabbou, F. (2019). Performance of machine learning techniques in the detection of financial frauds. Procedia Computer Science, 148, 45-54.

Snyder, H., \& Khreshchentsi, A. (2009). Intellectual capital and economic espionage: new crimes and new protections. Journal of Financial Crime, 16(3), 245-254.

State Financial Monitoring Service of Ukraine (2017). Typological research of the State Financial Monitoring Service of Ukraine for 2016, 2015, 2014. (In Ukrainian). Retrieved from https://finmonitoring.in.ua/wpcontent/uploads/2018/04/tipologichnidoslidzhennya-ua_2014_15_16.pdf.

Tikhonova, O.V. (2018). Features of financial crime in the United States in modern conditions. Legal Bulletin, 7, 2, 244-250. (In Ukrainian).

Tishchenkova, S., Cherniak, N., Chaplynska, Yu., \& Soldatenko, O. (2019). Transformation of the nature of terrorism in the conditions of glocal social space: political, legal, economic and communication aspects. Economic Annals-XXI, 178(7-8), 416. doi: https://doi.org/10.21003/ea.V178-01

Tishchenkova, S., Harcusha, A., \& Cherniak, N. (2018). Counter-terrorism strategies at the interstate level: economic, legal and sociocultural dimensions. Economic AnnalsXXI, $173 \quad$ (9-10), $4-9$. https://doi.org/10.21003/ea.V173-01

Tykhonova, O. (2019). Current issues of financial crime prevention. Criminology, 1, 150-153. (In Ukrainian). Retrieved from http://pgpjournal.kiev.ua/archive/2019/1/29.pdf.

Vitvitskiy, S.S., Kurakin, O.N., Pokataev, P.S., Skriabin, O.M., \& Sanakoiev, D.B. (2021a). Formation of a new paradigm of anti-money laundering: The experience of Ukraine. Problems and Perspectives in Management. 19, 1, 354-363.

Vitvitskiy, S.S., Kurakin, O.N., Pokataev, P.S., Skriabin, O.M., \& Sanakoiev, D.B. (2021b). Peculiarities of cybercrime investigation in the banking sector of Ukraine: review and analysis. Banks and Bank Systems, 16(1), 6980. doi:10.21511/bbs.16(1).2021.07

Wall, D. (2007). Cybercrime: The Transformation of Crime in the Information Age. Cambridge. Polity.

Western Union. (2021). Types of fraud. Fraudsters gain your trust and then steal your money. (In Ukrainian). Retrieved from https://www.westernunion.com/ua/uk/fraudawareness/fraud-types.html.

Zoldi, S. (2015). Using anti-fraud technology to improve the customer experience. Computer Fraud \& Security, 7, 18-20. https://doi.org/10.1016/S1361-3723(15)300671 . 